\title{
Pareto's Rule on global wealth and material distribution: The role of start-ups to change the dynamics of the rule.
}

\author{
Dr. Francis Kwadade-Cudjoe \\ FBCS, FIMIS, PhD, MBA, BSc (Hons) \\ Senior Lecturer, Knutsford University College and Adjunct Lecturer, \\ GIMPA Business School, Accra, Ghana.
}

\begin{abstract}
Pareto Rule of $80 / 20$ has a lot to inform the globe of the inequalities that prevail in human and business systems. This Rule of 80 /20 was first postulated by Juran in 1937, however the principles are still applicable in the modern society. It is so unfortunate that the $20 \%$ who controls $80 \%$ (vital few) of the global wealth, is still sustained. The $80 \%$ who controls only $20 \%$ (trivial many) of the global income still find themselves constricted to that position. This is a pathetic situation, and governments should do well to help start-ups and the marginalised in societies to extricate themselves from this mess. Poverty or unfair distribution of wealth should not be accepted as the order of life, and individuals should do well to come out of it. It is the hope of this article that when start-ups are given the necessary push by government to be sustainable, there would be a paradigm shift within the 80/20 Rule of Pareto.
\end{abstract}

Key words: Pareto rule, wealth distribution, start-up, dynamics, vital few and trivial many.

\section{INTRODUCTION}

Pareto was an Italian engineer, economist, sociologist and a philosopher who developed theories for income distribution and analysis of individuals' choices (Nugent, 2003). His work on 'vital few and the trivial many' (Nugent, 2003, p. 3) was postulated by Juran (1937) cited in Graham (1998), which led to the popularization of the Pareto's Rule. According to Pareto, wealth was unevenly distributed, and that approximately $20 \%$ of the population had $80 \%$ of the wealth, whilst $80 \%$ of the population had only $20 \%$ of the wealth (Nugent, 2003).

Furthermore, in the view of Rothkopf (2008), there was a growing concentration of power at the top, and these few top organisations determine the fate of the larger proportion of the global population, for example, pricing of essential commodities, like oil and gas. This therefore, implies that majority of organisations achieve marginal success, whilst only a few get overwhelming benefits within the business environment.

\section{WHAT IS PARETO'S RULE?}

Pareto's Rule states that approximately $20 \%$ of the population had $80 \%$ of the wealth, whilst $80 \%$ of the population had $20 \%$ of the wealth, which in brevity is given as ' $80 / 20$ '. This rule highlights how larger percentage (trivial many) of occurrences achieves little, whilst the smaller percentage (vital few) achieves much.

\section{Pareto's Rule and Starts-ups}

Paradoxically, Pareto's Rule highlights how trivial many (larger percentage) of occurrences achieves little, whilst the vital few (smaller percentage) achieves much. The application of this rule to the global business environment, could imply that approximately $80 \%$ of start-ups are likely to collapse, with only $20 \%$ surviving the harsh global economic conditions. Juxtaposing Pareto's rule of $80 / 20$ to the global industrial environment may support the fact that, 80 
percent of industrial systems are likely to fail at the inception phase, whilst only $20 \%$ are likely to become successful (Nugent, 2003), as envisaged by Pareto. As a consequence, investors and venture capitalists are always sceptical when investing in start-ups as announced by Sahlman (1997), and therefore, make sure that they are represented on the corporate boards that manage their investments.

\section{What is Start-up?}

According to Santoro (2012), start-up is a newly setup business or organisation, and which the work of an entrepreneur is always associated with. Start-ups are mostly ventured into by entrepreneurs, and entrepreneurship therefore, becomes one of the important theoretical frameworks to be considered when one thinks of what is entailed in start-ups. Start-ups are important ventures by entrepreneurs, which need every effort, including studies by researchers for encouraging their formation and good performance, and also sustaining their growth. Unfortunately, not many studies have been carried out by researchers on sustaining these ventures, as a greater percentage always folds up within the early (few) years of commencement of operation due to the numerous problems they encounter (Kwadade-Cudjoe, 2015).

\section{Who is Entrepreneur?}

Santoro (2012) and Sobel (2012) explained entrepreneurs as people who indulge in the process of discovering new ways of combining resources to undertake innovations, especially with business acumen in an effort to transform the innovations into economic ventures. According to Hornby (2001), entrepreneurs are people who carry out the act of making money by starting and running businesses, and especially taking financial risks with the hope of successfully operating the businesses. In another vein, an entrepreneur is one who undertakes innovations by organizing, managing, and assuming the risks of a business or enterprise in response to a perceived opportunity (Mises, 1949) cited in (Klein, 1999). Obviously, in undertaking innovations, the entrepreneur is also likely to be associated with starting a new business, commonly referred to as start-up. Entrepreneurship, is therefore, the act of being an entrepreneur.

Globally, entrepreneurs have always been churning out new businesses, but sustaining these enterprises has always been the bane of entrepreneurship (Kwadade-Cudjoe, 2015). Only a minute number of businesses survive the first few years of existence, and as such, making the attrition rate of new businesses notoriously high, as trumpeted by White (2004).

\section{Problems of Entrepreneurs}

Most entrepreneurs who ventured into start-ups have become financially paralyzed due to problems of failure of the venture (Sahlman, 1997). Coupled with the financial paralysis is where organisations go through long processes to contract loans from investors and venture capitalists, including banks, which may become difficult to pay, after mortgaging their properties to securing the loans. This normally leads to some entrepreneurs losing their valuable un/movable properties, and in addition, the collapse of their business. Entrepreneurs really go through hardships to be able to secure loans for their business. It should be noted that those who are fortunate to secure loans for their business, as mentioned above, are made to mortgage their valuable properties as security for the loans. Furthermore, the investors and venture capitalists put in place rigid rules to pursue their loans, and make sure they are represented on the corporate boards that manage their investments (Sahlman, 1997). 


\section{Banks and interest charge on loans}

Banks charge exorbitant interests on loans contracted by businesses, making organisations shy away from them. It is surprising to know that White (2004) revealed that the attrition rate of start-ups globally is notoriously high. The USA which happens to be the stronghold of entrepreneurship has a large number of new enterprises failing each year, about 50,000, and with even large enterprises seldom lasting one / two generations as success of business becomes ephemeral if not meticulously nurtured. In reality therefore, few entrepreneurs are able to achieve their entrepreneurial ideas, especially those who are fortunate to secure / raise investments, and are able to successfully repay these loans, which are always associated with huge interest rates. Hence, only few entrepreneurs survive this investment-ordeal (Rich \& Gumpert, 1985; Sahlman, 1997). This makes Pareto's rule of $80 \%$ of businesses (trivial many) commanding only $20 \%$ of clientele, whilst $20 \%$ of businesses (vital few) commanding a huge $80 \%$ of clientele, still valid.

\section{Effect of collapse of start-ups on entrepreneurs}

White (2004) revealed that the rate of grinding-down of start-ups globally is notoriously high. It is a fact that the collapse of business after the pumping in of initial investment, badly affects entrepreneurs (Rich \& Gumpert, 1985). Apart from the loss incurred and time wasted, most of these entrepreneurs do not overcome the tremor they go through, throughout their lives. This has seriously affected entrepreneurs and investors (when the loans are not paid), and consequently, dissuaded the latter from financing start-ups to enable entrepreneurs achieve their desired objectives of providing the products / services planned for the market.

\section{MANAGEMENT INFORMATION SYSTEM AS A DYNAMIC FACTOR}

Information is processed data which is meaningful to the user, whilst data is any raw material, fact or figure (Kwadade-Cudjoe, 2015). Management Information System (MIS) is defined by Nowduri (2011) as the study of people, technology and the organisation, and the relationships amongst them to ensure the overall efficiency of the system. Through these relationships, MIS can provide a vital information which as a resource can help management to efficiently plan, organize, direct, control (Dessler, 2004; Hitt, Black \& Porter, 2004) and govern (OECD, 2004) the organisation during the start-up phase and beyond.

According to Nowduri (2011), MIS can be described as people-oriented, since it is through people who use the facility on the activities of business, but with emphasis on service through technology, to provide the needed results. Though Nowduri describes MIS as people-centered, unfortunately, most often the people are limited to only those working in the organisation. It is important to consider and include customers / consumers who are equally important, and also stakeholders within the business environment, and as one of the revered stakeholders (OECD, 2004) for a successful business climate. Customers patronize the products and services of the organisation, and as such are one of the important stakeholders within the organisation to be considered whenever evaluating the business environment.

Hence, when the information on their purchasing records is monitored, it can lead to improvement and contribute to the growth of the organisation. For a business therefore, to function properly and report on its activities accurately, there is the need for the people of the organisation to use information systems at the various levels of operation to collect and store the data gathered from these levels. Subsequently, the processing of the data will generate the needed information for effective decision making by management of the organisation. The information (or output) has variously been called different names, such as resource, report and database; however, data that is processed to help management make meaningful, effective and 
timely decisions is called information (Institute of Information Technology, 1996). Information is vital for the effective management of the organisation. Businesses become crippled when they do not have the information needed to help define and report on the operations performed. In the current technological and global age, competition among organisations is keener and more pronounced for competitive advantage (De Wit \& Meyer, 2004).

An enterprise that allows its business to be crippled due to lack of information for accurate reporting on activities performed is doomed to collapse and therefore, will be wiped out entirely. This might however, be one of the causes that has led to greater number of businesses, including start-ups, to die-off early, instead of surviving the start-up phase to the next level (and even higher) to offer the needed products and services to clientele. The importance of information management within the organisation for efficient / effective monitoring and management of the organisation has therefore, become important as it has tremendous effect on business of organisations, particularly start-ups, to be sustainable.

\section{Resourcing start-ups with Management Information Systems}

Start-ups need databases, as they are generally helpful, especially where they contribute to the processing and managing of specialized managerial tasks (Institute of Information Technology, 1996) cited in (Kwadade-Cudjoe, 2015) within the business.

Databases may be developed for general use (which is normally purchased off-the-shelf, that is, at the counter), in-house or by a contractor for a specific functional task, (where the software could be termed as tailor-made) - (Kwadade-Cudjoe, 2015).

Business Process Re-engineering (BPR) is one of the areas, where specialized databases are recommended for achieving dramatic improvements in critical, contemporary measures of performance, such as cost, quality, service and speed to maximize value-added content of businesses. Thus, thereby enhancing the competitive advantage of start-ups by entrepreneurs (Hammer, 1990; White, 2004). Databases are important for management decision making activities to enable entrepreneurs of start-ups to efficiently plan, direct, control and govern (Dessler, 2004; OECD, 2004; Hitt et al., 2004) operational performances and growth of their businesses.

There are three main approaches for designing databases - Hierarchical, Network and Relational Database Management System (RDBMS) - but the latter gives the best relationship among the data elements for example, one-to-one and one-to-many relationships, which is a pre-requisite for database development (Kwadade-Cudjoe, 2015). It is therefore, the recommended approach for developing databases (Brooks et al., 1982).

\section{MIS operates in the environment of technology}

Technology, according to Hornby (2001), is scientific knowledge used practically to design new machines to solve problems in industry. MIS is the medium through which technology (e.g. computer system) can be used to solve organisational problems. According to Gaines, Hoover, Foxx, Matuszek \& Morrison (2012), MIS that is properly designed and implemented has become an even more valuable strategic resource for improving organisational competitive advantage.

Many organisations, including Microsoft, Amazon, Dell and IBM have used technology and / or e-commerce to carve a niche for their businesses (Thompson \& Strickland, 2001). These and other organisations have been able to use technology (for example, the computer system and internet) to create higher-market-share for their organisations, and also turned-around human 
lives. Technology, as one of the institutional-based drivers (Peng, Wang \& Jiang, 2008), can be used to achieve competitive advantage for the organisation (Thompson \& Strickland, 2001). Modern businesses therefore, thrive on the use of technology, especially organisations that go global, for example multinational conglomerates (MNCs), as they need the use of technology and internet to assert themselves internationally in the industries and markets they operate in (Thompson \& Strickland, 2001).

Business computers that originated from technology were earlier used primarily for relatively simple operations for example, payroll, budget and general ledger preparation until the operations became more complex to involve the storage of large amount of data needing processing into desired outputs for management decision making activities. The Computer System, according to Hornby (2001) is a versatile programmable machine, which automatically carries out editing, control and, arithmetic and logical operations on data fed into it to produce information. Many applications have been created from the information for different assignments based on management needs within the enterprise.

Furthermore, technology is useful for monitoring corporate performance and sustaining growth, which as a management resource will eventually alleviate one of the major problems faced by entrepreneurs during the start-up phase of their businesses. Technology as a tool, is versatile to aid entrepreneurs in monitoring corporate performance for sustaining growth to overcome the early collapse of start-ups. This does not negate the fact that the management skills of the entrepreneur (White, 2004) and process control of the enterprise are vital to complement the technological enhancement (Spinner, 1992; Ward, 1995). Entrepreneurs are counselled to control and monitor organisational performance with the use of technology to enable them sustain growth of start-ups.

\section{Global Environmental Condition}

Globally, the environment is everything surrounding us; these are the living / biotic factors, such as climate, soil and living organisms and non-living / abiotic things, such as chemical and other natural forces. The natural environment encompasses all living and non-living things occurring naturally (Daly, 2008).

Environmental sustainability has been the concern of all governments, due to the rampart deterioration of the earth, leading to fires and floods ravaging most countries, e.g. Northern California in the USA and India respectively, not excluding Africa which has had its fair share of the destruction (CNN, 2019; BBC, 2019a). Furthermore, fires in Australia, which started in September 2019 and continued into January 2020, have caused enormous havoc to, example, human and animal lives, plants and buildings (Chiwaya, Wu, \& Muccari, 2019) cited in (Cales, 2020). These fires were started by drought and extreme heat, killing over 24 people and destroyed more than 1,000 homes; according to Environment Minister, Sussan Ley, up to 30\% of the koala (animal) population located on the coast of New South Wales might have been killed (Chiwaya, Wu, \& Muccari, 2019) cited in (Cales, 2020). See appendices 1 and 2 for illustrations on the havoc caused by the wildfires in Australia.

\section{Concerned Environmental Groups}

Concerned citizens in most countries of the globe, for example, UK, Australia and France have demonstrated to prompt their governments to introduce interventions to avert the deterioration of the environment (BBC, 2019b). Why did the citizenry of these nations demonstrate? This was as a result of the environment, which happens to be the economic backbone of peoples living on the earth, being destroyed by the activities of these same 
peoples, whilst governments look unconcerned. Concerned social groups, national organisations and the citizenry of the affected nations realized that, they have to make their voices heard by their governments to curb the destruction of the environment. Unfortunately, when the environment is destroyed, it is the business of entrepreneurs, including start-ups, which suffer.

\section{Environmental sustainability}

The environment is normally destroyed through, for examples, fires ignited through inappropriate actions, cutting down of trees and not re-planting with new seedlings, and mining for minerals and not re-claiming the soil fertility. This, in turn, affects the economic activity on the land. Most businesses and organisations of entrepreneurs are daily being destroyed through fires, floods and other natural disasters, due to lack of effective maintenance of the environment by governments.

Daly (2008), one of the earlier pioneers of ecological sustainability explained Environmental Sustainability from a maintenance of natural capital viewpoint in 1990 as:

1. Renewable resources - the rate of harvest should not exceed the rate of regeneration (sustainable yield);

2. Pollution - the rate of waste generation from projects should not exceed the assimilative capacity of the environment (sustainable waste disposal); and

3. Non-renewable resources - the depletion of the non-renewable resources should require comparable development of renewable substitutes for that resource.

The sustainability of the environment is surely related to the success of economic activities performed within the environment. Climate change and other natural disasters have had its toll on global businesses, and most global businesses are really undergoing hard times, as prevailing environmental condition is harsh, for example, unstable climate, floods, fires and shortage of water. These occurrences affect the performance of organisations, and therefore, the economy of most countries, as lands on which these businesses are situated are easily affected, thereby affecting the repayment of loans contracted from investors and venture capitalists by entrepreneurs (Sahlman, 1997).

\section{GOVERNMENTS SHOULD HELP ENTREPRENEURS TO SUSTAIN CORPORATE GROWTH}

It is a fact that the collapse of start-ups after the initial investment has been pumped into them affects entrepreneurs, and apart from the loss incurred and time wasted, most of these entrepreneurs do not overcome the tremor they go through, throughout their lives, and eventually pass on. This has seriously affected entrepreneurs to the extent that most of them have abandoned the profession, and consequently, affecting the springing up of new start-ups. The above revelation goes a long way to make Pareto's rule of ' $80 / 20$ ' still important. This is where governments should come in to assist entrepreneurs.

Some governments help Small \& Medium-Sized Enterprises (SME) with soft loans to commence business. Mustapha (2012), appropriately informed that a Ghanaian savings and loans company, Midland savings, has reiterated its commitment to provide funds to SMEs so as to help grow the Ghanaian economy, and the government of Ghana has also announced to use part of the oil revenue to grow the SMEs (Sam, 2012).

Government should also help entrepreneurs of start-ups to equally get soft loans to manage their businesses, as these businesses are normally able to employ more unemployed labour within and beyond the nation, than the public service. 
The high failure rate of start-ups globally has made most of the innovations emanating from entrepreneurs useless; this has greatly affected entrepreneurs and rendered their organisations shambolic and chaotic, and as such, unsustainable.

\section{RECOMMENDATION FOR ENTREPRENEURS}

The key practical and valuable recommendations for entrepreneurs are listed below:

i. in order for entrepreneurs to have their dreams and innovations to survive the turbulent period of their businesses collapsing at the start-up phase, they should tread cautiously when contracting loans for their start-ups.

Normally, after a large sum of money is pumped into the start-up (Rich \& Gumpert, 1985), the borrowed money would surely have to be paid back at a certain period. The entrepreneur must plan properly for the repayment of the loan, so as not to encounter problems that would lead to early collapse of the business, which would sound the beginning of the end of that entrepreneur;

ii. entrepreneurs as owners of MNCs who favourably command markets within the global business environment and, as such, have large capital mobilization in their organisations, strategic alliances, mergers, joint ventures and acquisitions spread globally (Dessler, 2004; De Wit \& Meyer, 2004; Hitt et al, 2004), should seriously use the application of effective modern technology in their organisations, to enable them survive the high attrition rate businesses (including start-ups) generally go through;

iii. management of start-ups are being advised to consider and take time to understand the principles involved in generating good organisational MIS for efficiently / effectively monitoring the organisation's activities / tasks. Globally, the attrition rate of start-ups is notoriously high, as according to White (2004), in the US which happens to be the bastion of entrepreneurship, about "50,000 new enterprises fail each year" (p. 66) with even large enterprises seldom lasting one / two generations.

This is therefore, an opportune time for organisations to get involved with the development of appropriate application software to monitor corporate performance and growth of their enterprises for the survival of the companies;

iv. it is envisaged that a competent Information Technologist, which is the most critical success factor (CSF) - (Thompson \& Strickland, 2001) should be engaged to develop the application software that would generate the needed information for monitoring the corporate performance of start-ups, right from their inception for sustaining growth (Jiang, Klein \& Balloun, 1996);

v. policy makers of governments globally, should make room for assisting entrepreneurs to contract soft loans from investors and venture capitalists for the start-ups that spring up in their countries. This would enable them have a better repayment period for the loans contracted, which would help them become successful and thereby, survive the unfortunate failure most start-ups normally go through. Entrepreneurs suffer in silence as most of their innovations do not live long after going through the hectic period of securing loans (Rich \& Gumpert, 1985) to commence their businesses, due to the high attrition rate of start-ups (White, 2004); and

vi. Government should do well to put up plans to curb the degradation of the environment, which affect entrepreneurs, including start-ups, when the environment is subjected to man-made destruction, which could be averted by pragmatic plans of governments working with environmental social groups to sustain the environment. 


\section{References}

BBC (11 th Aug. 2019a). India floods: More than a hundred dead after torrential rain. Retrieved from: https://www.bbc.com/news/av/world-asia-india-45091665/India-floods-.....

BBC (2 $2^{\text {nd }}$ Dec. 2019b). Why is there a backlash against climate policies? Retrieved from: https://www.bbc.co.uk/programmes/w3csth0.

Brookes, C. H. P., Grouse, P. J., Jeffery, D. R., \& Lawrence, M. J. (1982). Information systems design. Australia: Prentice-Hall.

Cales, A. (10 th Jan. 2020). The devastation of Australia's wildfires. Retrieved from https://farragutanchor.org/8298/features/the-devastation-of-australias-wildfires/

CNN (5 ${ }^{\text {th }}$ Dec. 2019). How AI is helping spot wildfires faster. Retrieved from: https://edition.cnn.com/2019/12/05/tech/ai-wildfires/index.html.

Daly, H. (2008). Ecological economics and sustainable development: Selected Essays. NY, USA: Edward Elgar. Dessler, G. (2004). Management-principles and practices for tomorrow's leaders (3 ${ }^{\text {rd }}$ edition). USA: Prentice Hall Inc.

De Wit, B., \& Meyer, R. (2004). Strategy: Process, content and context (3 ${ }^{\text {rd }}$ edition). Italy: Thomson Learning.

Gaines, C., Hoover, D., Foxx, W., Matuszek, T., \& Morrison, R. (2012). Information systems as a strategic partner in organizational performance. Journal of Management and Market Research, 10(1), May 2012. ISSN: 1941-3408.

Graham, A. (1998). The vital few, the trivial many. Internal Auditor, 55(6), Dec. 1998. ISSN: 00205745.

Hammer, M. (1990). Reengineering Work: Don't automate, obliterate, Harvard Business Review, July-August 1990 , pp.104-111.

Hitt, Black, \& Porter (2004). Management (1 ${ }^{\text {st }}$ edition). eBook. USA: Hall Inc.

Hornby, A. S. (2001). Oxford advanced learner's dictionary (6 $6^{\text {th }}$ edition). Oxford: Oxford University Press. Institute of Information Technology (1996). Infotec. Accra: IIT.

Jiang, J., Klein, G., \& Balloun, J. (1996). Ranking of system implementation success factors, Project Management Journal, 27 (4). pp. 50-55.

Klein, G. P. (1999). Entrepreneurship and corporate governance. The Quarterly Journal of Austrian Economics. 2 (2), Summer 1999.

Kwadade-Cudjoe, F. (2015). Sustaining Corporate Growth: Exploring the role of MIS in monitoring Companies' Performance. Saarbrucken, GE: Lambert Academic Publishing. ISBN: 978-3-659-80638-4.

Mustapha, S. (Aug. 2012). Midland savings to increase support to SMEs. The Ghanaian Times, ISD 4/7/90.

Nowduri, S. (2011). Management information systems and business decision making: review, analysis and recommendations, Journal of Management and Market Research, 7(9). April 2011, ISSN: 1941 - 3408.

Nugent, J. H. (2003). Plan to win: Analytical and operational tools-Gaining competitive advantage. USA: McGraw Hill.

OECD (2004). OECD Principles of corporate governance. ISBN: 92-64-01597-3 - No. 535332004.

Peng, M. W., Wang, D. W., \& Jiang, Y. (2008). An institution-based view of international business strategy: a focus on emerging economies, Journal of International Business Studies, 2000.

Rich, S. R., \& Gumpert, D. E. (1985). How to write a winning business plan. Harvard Business Review, May, 1985.

Rothkopf, D. (2008). The 20/80 Rule. Video, stanford's technology ventures program. (28 February, 2011).

Sahlman, W. A. (1997). How to write a great business plan, Harvard Business Review. July-August 1997.

Sam, S. (2012, November 12). Government to use part of oil revenue to grow SMEs. The Ghanaian Times, ISD 4/7/90.

Santoro, G. (2012). Entrepreneurship (1 ${ }^{\text {st }}$ edition). Delhi: University Publications. ISBN: 978-81-323-3994-6.

Sobel, R. S. (2012). Entrepreneurship. Retrieved from https://www.econlib.org/library/Enc/Entrepreneurship.html.

Spinner, M. P. (1992). Elements of project management: Plan, schedule and control. Englewood Cliffs: Prentice-Hall. Thompson, A. A. Jr., \& Strickland, A. J. III (2001). Crafting and executing strategy (12 ${ }^{\text {th }}$ edition). NY: McGraw-Hill. 
Ward, J. (1995). Project Pitfall, Information system management, 12(1). pp. 74-76.

White, C. (2004). Strategic management, New York: Palgrave Macmillan. ISBN: 9781403904003.

\section{APPENDICES}

\section{Appendix 1}

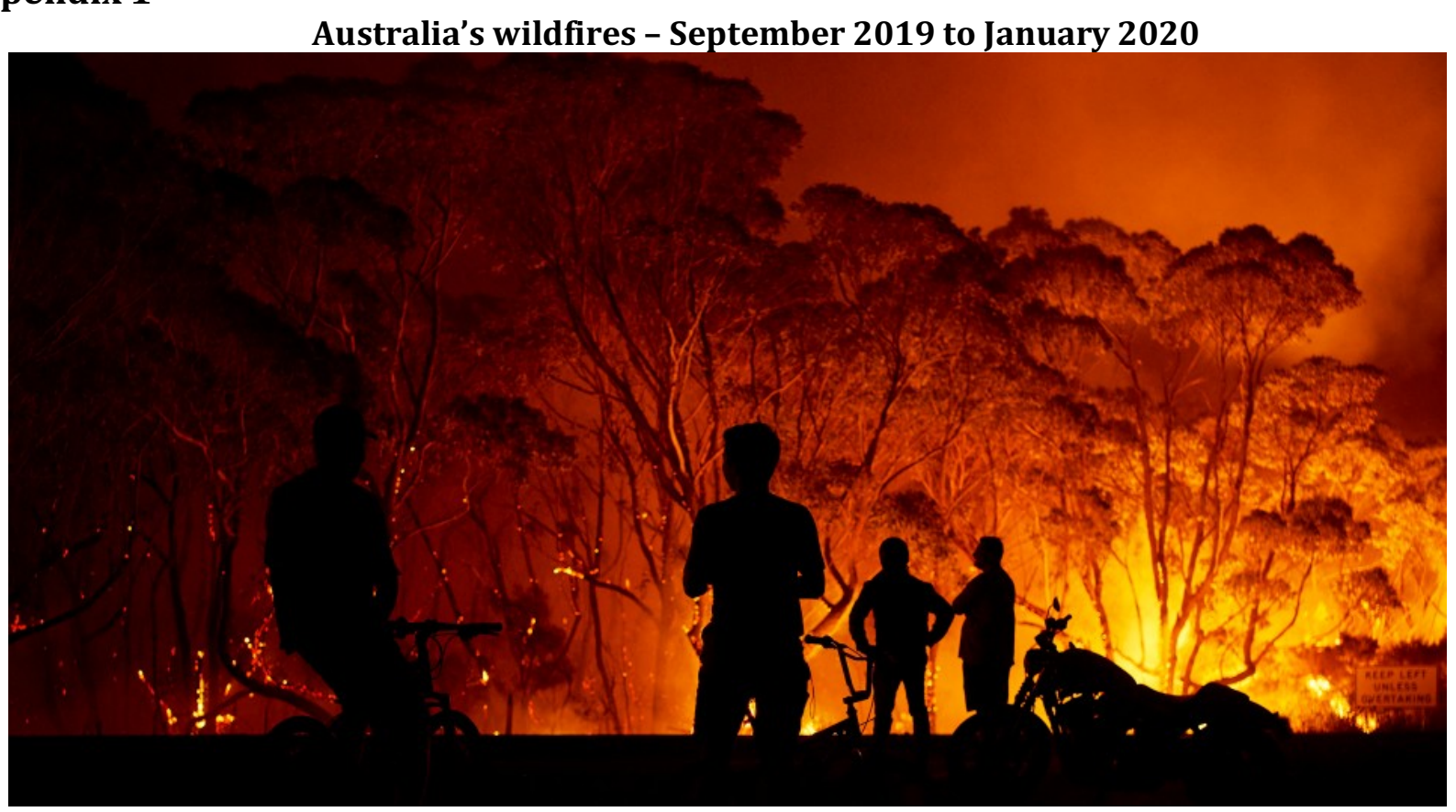

Source: The Anchor, The student news site of Farragut High School.

\section{Appendix 2}

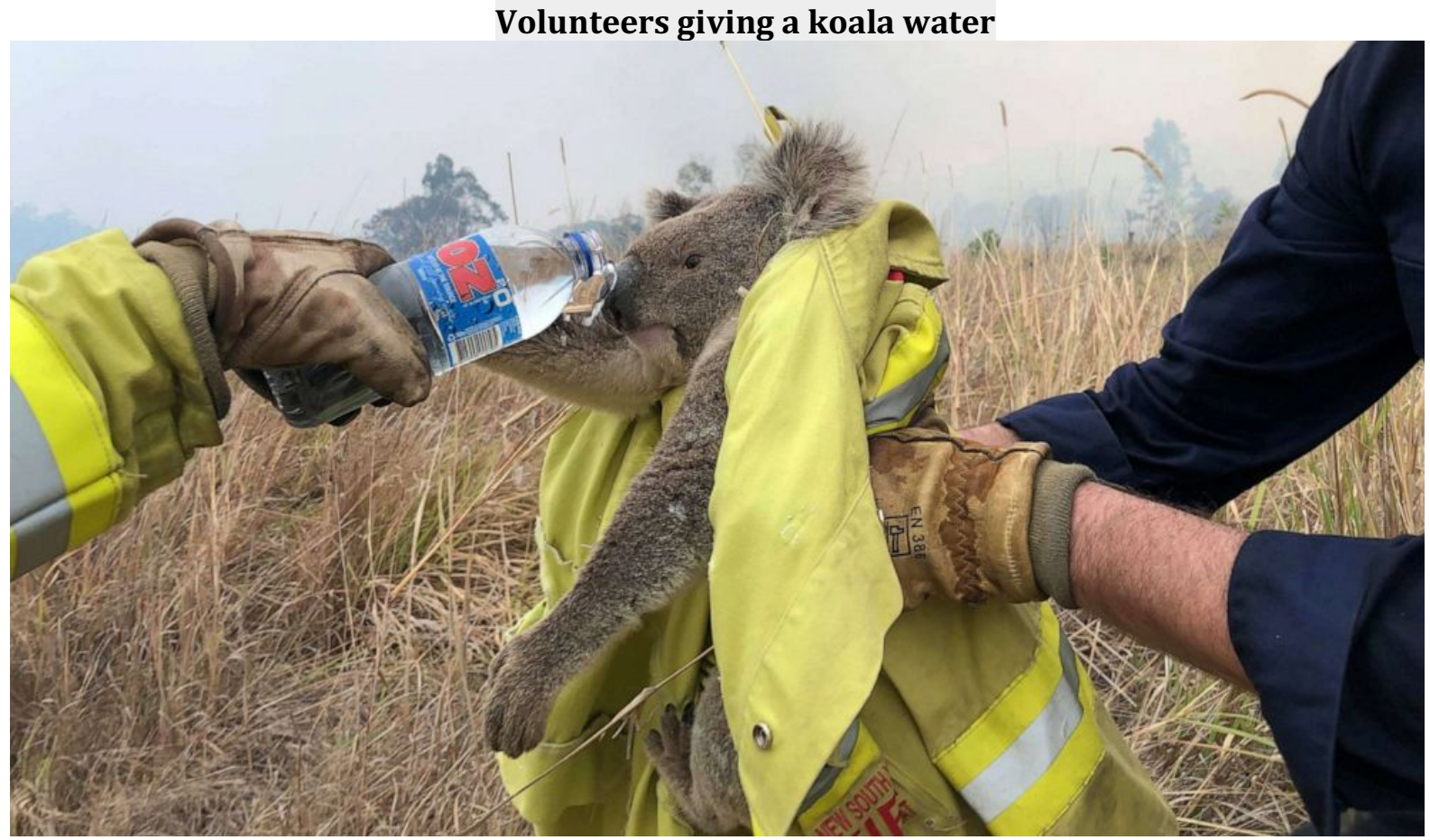

Source: The Anchor, The student news site of Farragut High School. 